\title{
INTEGRATION OF EDUCATION, SCIENCE AND PRODUCTION
}

\author{
CREATION OF ADVANCED MACHINE BUILDING PRODUCTION \\ ON THE BASIS OF RECENT METHODS OF DESIGN OF ARTICLES \\ AND FLEXIBLE PROCESSES OF PRECISION TREATMENT OF MATERIALS
}

\section{V. Dombrovskii ${ }^{1}$}

Translated from Metallovedenie i Termicheskaya Obrabotka Metallov, No. 11, p. 3, November, 2012.

The "Motovilikhinskie Zavody" Company is a holding created on the basis of one of the oldest defense plants in the Ural Region. Today it produces defense articles, oilfield equipment and highway engineering articles. The metallurgical production is also developed.

The Perm National Research Polytechnic University (PNIPU) has been founded in 1953. The teaching staff consists of 1500 persons including 2 Academicians and 4 Corresponding Members of the Russian Academy of Sciences, 200 professors, doctors of science, and over 700 assistant professors, candidates of science. In 2009 the university has been awarded a status of a National Research University.

The decree of the Government of the Russian Federation No. 218 of 2010 "On Measures of State Support of the Development of Cooperation between Russian Higher Educational Institutions and Organizations Implementing Complex Projects of Creation of High-Technology Production," which stipulates governmental financial support of cooperation between higher education institutions and industry aimed at creation of innovative productions, meets the plans of the "Motovilikhinskie Zavody" Company. In the same year the Board of Directors of the Company has approved a program of investment into the production of ordnance systems. The volume of the investment is 750 million rubles. The program poses an ambitious task of becoming a No. 1 plant in Russia in the production of ordnance systems. Jointly with the PNIPU the Company has started a project aimed at creation of an advanced machine-building production on the basis of recent methods of design of articles and flexible processes of precision treatment of materials. The project has a task to

“Motovilikhinskie Zavody” Company, Perm, Russia. transform the "Motovilikhinskie Zavody" into a flexible advanced dual-purpose production making special-purpose and civil machines.

The research and technological possibilities of the Perm National Research Polytechnic University and of the "Motovilikhinskie Zavody" Company will be united for meeting the market demand for articles of defense and civil machine building. The works of the scientists of the PNIPU will help in solution of a number of problems arising in the production and treatment of high-quality steels, prolonging the life of articles of the arms industry, creating training simulators for mastering special machines. Implementation of the project will make it possible to reduce the consumption of power, reject the outdated technologies, raise the labor productivity by at least $20 \%$ by introducing advanced processes and automation, and provide high reliability and competitiveness of domestic produce.

The joint venture with the PNIPU matches such priorities of the "Motovilikhinskie Zavody" Company as innovations and efficiency. The Company has an aim to lead the list ordnance producers in Russia and to become one of the most efficient machine-building enterprises in the country, which requires a high-end technology effort. Joint work with the PNIPU, an old and reliable partner of the Company, will help in solution of this difficult and important task. The joint venture should also become a powerful incentive for raising the research and development standard at the PNIPU to a new level. We expect fruitful cooperation between the University and the Company in the sphere of high technology. This will create a base for further cooperation between PNIPU researchers and enterprises of the Ural Region. 